\title{
Pharmacokinetics of Selegiline in a Rabbit Model
}

\author{
H. Kalász ${ }^{1, *}$, K. Tekes ${ }^{2}$, Z. Pöstényi ${ }^{1}$, E. Vizvári ${ }^{3}$, P. Sótonyi ${ }^{4}$, D. Szabó ${ }^{5}$ and E. Tóth-Molnár ${ }^{3}$
}

\author{
${ }^{I}$ Department of Pharmacology and Pharmacotherapy, Semmelweis University, Budapest, Hungary \\ ${ }^{2}$ Department of Pharmacodynamics, Semmelweis University, Budapest, Hungary \\ ${ }^{3}$ Department of Ophthalmology, University of Szeged, Szeged, Hungary \\ ${ }^{4}$ Heart and Vascular Center, Semmelweis University, Budapest, Hungary \\ ${ }^{5}$ Department of Medical Microbiology, Semmelweis University, Budapest, Hungary
}

\begin{abstract}
Time-dependent distribution of selegiline was monitored in various tissues of rabbits treated with a dose of $30 \mathrm{mg} / \mathrm{kg}$ intravenously. Selegiline content was determined by validated RPHPLC method following 5,15, 30, 60 and 120 minutes of treatment. The present study confirming earlier data showed that selegiline readily penetrates through the blood brain barrier, however, as a new result, high selegiline concentrations were measured in the lacrimal glands, lungs and testes as well as in the eyes of rabbits at each time point studied. When selegiline concentrations in the different eye segments were determined, a time-dependent decline of selegiline tissue levels was observed in the iris, the cornea and the intraocular lens, while the maximum level of selegiline in the retina found at $15 \mathrm{~min}$ and even at $60 \mathrm{~min}$, was similar to that determined at $5 \mathrm{~min}$ following administration.
\end{abstract}

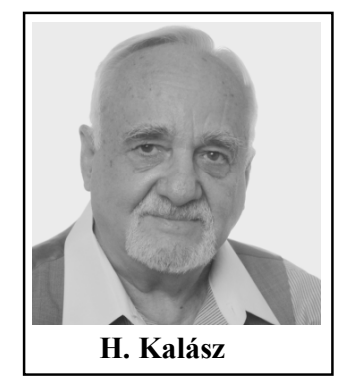

Keywords: Selegiline, pharmacokinetics, rabbit, blood-brain penetration, blood-testis penetration, iris, cornea, retina.

\section{INTRODUCTION}

Selegiline is one of the most widely used monoamine oxidase B inhibitors. Its human indications include Parkinson's disease [1,2], and depression and its advantages were suggested in the study of the pathomechanism of Alzheimer's disease [3]. Its beneficial effects in Parkinson's disease were well established by its selective and irreversible inhibition of MAO-B enzyme in the brain [4], and also by its inhibitory effect on high affinity dopamine reuptake [5-7] as well as its dopamine releasing effects following chronic treatment [8].

Lifespan was prolonged [9-12], the cognitive function [13] and sexual activity of rats were definitely improved by chronic treatments of selegiline, which were reported in a number of in vivo studies [14-16]. Nowadays, these effects are summarized as senolytic [17]. According to Kitani et al [9] the lifespan-prolongating effect of selegiline can be explained by its upregulating effect in the dopaminergic brain areas of several animal species (mice, rats, hamsters and dogs) on the activity of anti-oxidant enzymes such as catalase (CAT) and superoxide dismutase (SOD). This upregulation of CAT and SOD was also found in several extra-cranial organs (the adrenal glands, heart, kidney and spleen) and mobilization of humoral factors (interferone- $\gamma$, tumor necrosis factor, etc.) was also observed by Kitani et al [9]. At the same time, no explanation for the increase in sexual activity was provided [14-16]. However, selegiline's

*Address correspondence to this author at the Department of Pharmacology and Pharmacotherapy, Semmelweis University, H-1089 Budapest, Nagyvárad tér 4, Hungary; E-mail: drkalasz@gmail.com oral bioavailability was found drastically (10- to 20-fold) increased in females taking oral contraceptives [18].

Selegiline is a lipophilic compound with a positive $\log \mathrm{P}$ value $[19,20]$. Its metabolism [21] yields three major metabolites, such as desmethylated selegiline ((-)-nordeprenyl, which keeps the MAO-B inhibitory effect of selegiline), despropargyl selegiline ((-)-methamphetamine) and desmethyldespropargyl selegiline, which is the (-)-amphetamine metabolite. The metabolism of selegiline is essentially carried out by cytochrome P 450 (CYP) enzymes [22-24]. Benetton et al. [25] used recombinant human CYP enzymes to identify which ones are mainly involved in the metabolism of selegiline, thereby taking part in the removal of selegiline from the body. Their experimental results show that the major enzymes in selegiline $\rightarrow$ metamphetamine conversion are CYP 2C19, CYP 3A4 and CYP1A2. Kamada et al [24] also attributed an important role to CYP2D6 in the metabolism of selegiline. Tóth-Molnár et al. [26] determined selegiline metabolites in the rabbits' blood, livers, kidneys and eyes.

To avoid the first-pass effect of selegiline, buccal films were impregnated with selegiline nanospheres and the comparative pharmacokinetics profile of the buccal film with oral solution was studied in rabbits [27]. Orally disintegrating selegiline tablets [28] can also be used for the same reason.

Pharmacokinetics (PK) of selegiline $\left(\mathrm{Jumex}^{\circledR}\right)$ in rats, beagle dogs, mini-pigs has been published, in addition to that of humans. However, pharmacokinetics of selegiline (without any advanced formulation) has not yet been published on rabbits. The rabbit model can be preferred when the distribution of selegiline $\left(\right.$ Jumex $\left.^{\circledR}\right)$ levels in the different eye segments (the iris, cornea, retina, lens) should be determined and compared. 
<smiles>C#CCN(C)[C@@H](C)Cc1ccccc1</smiles>

Fig. (1). The chemical structure of selegiline (L-deprenyl).

Only few publications detail the effect of selegiline on eyes [29]. Recently high selegiline levels were published on the rat eyes [30]. The distribution of selegiline in the eye segments has not been studied. The presence of MAO-B activity in bovine eyes was detected [31], in the retina, the optic nerve, the iris and the epithelium. However in the rabbit retina the MAO-A isoform was shown to be dominant [32].

$\mathrm{Xu}$ et al. [33] studied the effect of selegiline in cultured retinal neurons, and found dose-dependent blocking of apoptosis in the concentration range from 0.001 through $10 \mu \mathrm{M}$.

This paper introduces the pharmacokinetics of selegiline in rabbit tissues, including its time-dependent distribution in the serum, the brain, the cerebrospinal fluid, the testis, the liver, the lungs, the lacrimal glands and in eye segments (the cornea, iris, lens and retina).

\section{EXPERIMENTAL}

Treatment of animals: Male white New Zealand rabbits weighing $2.0 \pm 0.2 \mathrm{~kg}$, were purchased from Dévai Farm (Kondoros, Hungary). Selegiline (L-deprenyl, Fig. 1), freshly dissolved in saline, was intravenously (i.v.) administered through the ear vein. The protocol was approved by the Ethical Committee for Protection of Animals in Research in the Department of Pharmacology, University of Szeged (XIII:/1211/2012), being in accordance with the Directive 2010/63/EU of the European Parliament.
Hardware of HPLC: The chromatographic analyses were performed using a JASCO system (Tokyo, Japan supplied by the local distributor ABL\&E Jasco Kft, Budapest) equipped with a DG-2080-54 Degasser, PU-1580 Pump, AS2057 Plus Autosampler (temperature kept at $4{ }^{\circ} \mathrm{C}$ ) and with an Antec Leyden Decade Amperometric Detector at $\mathrm{E}_{\mathrm{ox}}$ : $0.9 \mathrm{~V}$, (Zoeterwoude, the Netherlands) and a UV-975 $\mathrm{UV} / \mathrm{V}$ is Detector (operated at $265 \mathrm{~nm}$ ). All chromatograms were stored and evaluated using a Borwin 1.50 Chromatography software (JMBS, Le Fontanil, France). The stationary phase of separation was a Zorbax Rx-C18 octadecyl silica column $(4.6 \mathrm{~mm} \times 250 \mathrm{~mm}, 5 \mu \mathrm{m})$ (Agilent Technologies, supplied by the local distributor Kromat Kft., Budapest, Hungary). The mobile phase was a phosphate/citric acid buffer ( $\mathrm{pH}$ 3.7) containing sodium 1-decanesulfonate and acetonitrile. The flow rate of the mobile phase was $1 \mathrm{ml} / \mathrm{min}$, the column was kept at $35^{\circ} \mathrm{C}$ and the injection volume was $75 \mu \mathrm{l}$. Conditions of sample treatments and validation of HPLC determinations are detailed in our recent publications $[30,34]$. HPLC of rabbit iris samples is given in Fig. (2).

\section{RESULTS}

Samples from the serum, brains, CSF, lungs, lacrimal glands, testes and eye segments of selegiline-treated rabbits showed excellent and time-dependent distribution of the compound in the tissues studied. The time-dependent levels of selegiline in various organs and body fluids of rabbits injected with a $30 \mathrm{mg} / \mathrm{kg}$ intravenous dose following 5, 15, 30, 60 and 120 minutes are shown in Table 1. The selegiline concentrations in the brains were higher than in the serum at all points of time studied except at $120 \mathrm{~min}$. In the cerebrospinal fluid selegiline concentrations were only about half of that in the serum. In the livers, selegiline concentrations were about $60 \%$ of that in the serum at each time point.

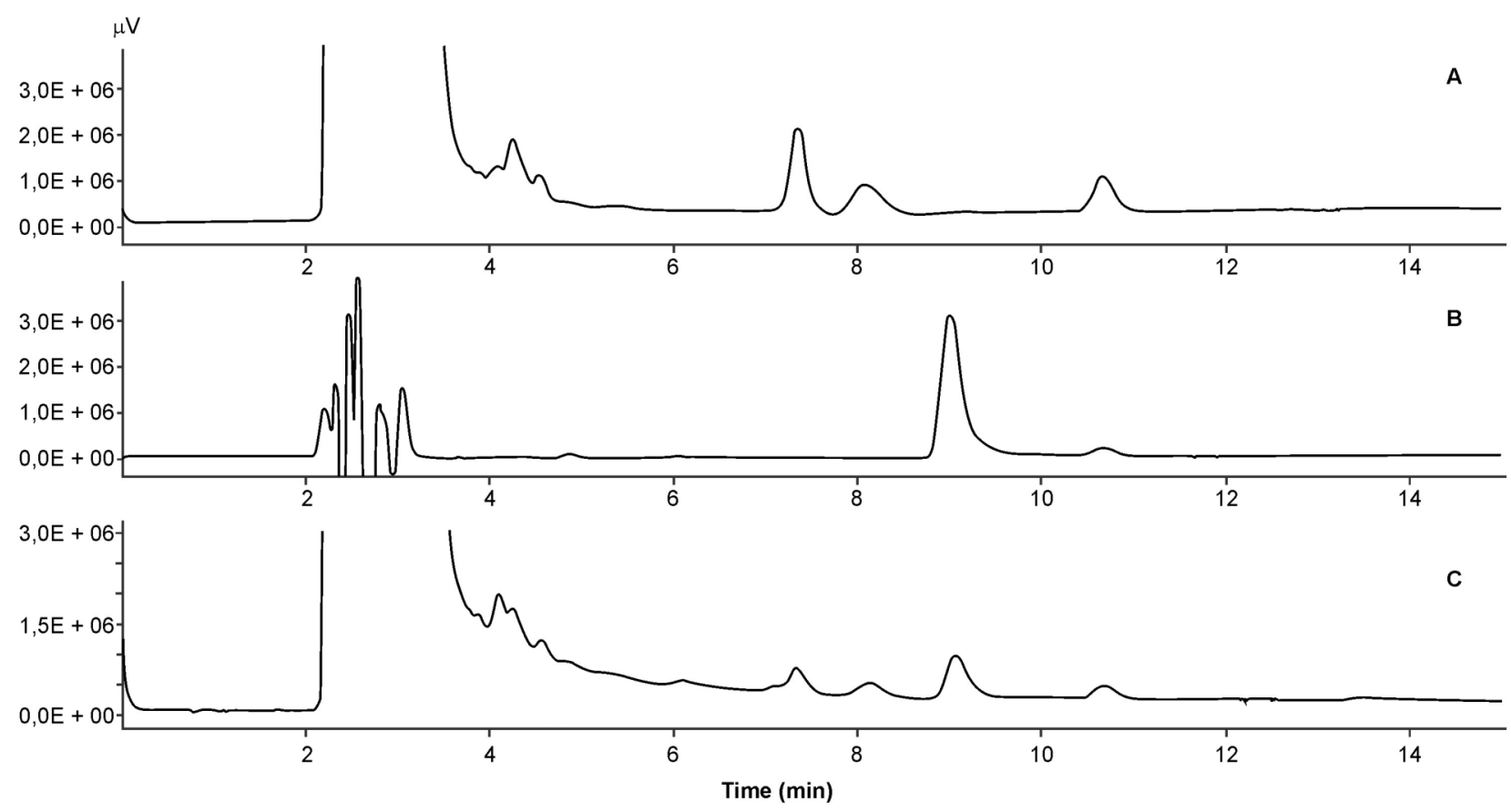

Fig. (2). HPLC of rabbit iris samples using an Amperometric Detector at $\mathrm{E}_{\mathrm{ox}}: 0.9 \mathrm{~V}$. (A: blank iris, B: spiked iris, C: iris sample from treated rabbit). The peak of selegiline is at 9 min. 
Interestingly, in the lacrimal glands the selegiline concentrations showed very high levels, with the highest value following 30 minutes after administration, when it was twenty eight-fold higher than that in the serum. This high concentration remained even at the end of the observation period (two hours after selegiline administration). Selegiline tissue levels in the testes were also strikingly very high with a maximum at $15 \mathrm{~min}$ and even at $60 \mathrm{~min}$ they were much higher than in the serum. Among the eye segments, selegiline concentrations at $5 \mathrm{~min}$, the iris showed the highest tissue concentration with continuous decline, while in the retina the maximum was observed at 15 min followed by a decline producing similar levels in the serum in the first hour following administration. When the tissue concentration ratios in the retina were compared to the other eye compartments, the following ranking could be seen at $5 \mathrm{~min}$ : iris $>$ cornea $>$ retina, while at each other time point the ranking was: retina $>>$ iris $>$ cornea. At the same time the selegiline concentrations in the lacrimal glands were almost a magnitude of order higher than in any of the eye segments.

\section{DISCUSSION}

There are two possibilities for the termination of the effect of xenobiotics administered to living organisms (1) nonphysical cessation by their metabolism, that mainly happens in the liver by dealkylations; (2) physical removal of the parent compound and/or its metabolites mainly done by the kidney, bile, perspiratory gland, salivary gland and lacrimal gland as well as by expiration through the lungs. In the case of selegiline both the parent compound and its metabolites are effectively removed [35].

Pharmacokinetics of selegiline has not yet been published in rabbits. Using a validated RP-HPLC method $[30,35]$ as a new result, in our present study, we have demonstrated strikingly high selegiline tissue levels in the lacrimal glands and testes as well as in the eye segments of rabbits. The selegiline level in the lacrimal glands of rabbits showed upmost high concentrations at 30 minutes following administration. It is suggested, that selegiline's MAO inhibitory effect in the lacrimal gland results in elevated dopamine level, which was reported to stimulate ion transport in the corneal epithelium [36].

The anti-parkinsonian effect of selegiline is mainly based on the selective inhibition of monoamine oxidase B enzyme in the brain [2]. It is evident that selegiline can also show similar selective and irreversible inhibition of monoamine oxidase B enzyme in any other organs of the body wherever it is present. Inhibition of MAO activity can lead to decreased inactivation of endogenous MAO substrates (dopamine, phenylethylamine, serotonin etc.).Inhibited MAO activity may be one of the factors contributing selegiline's decreasing effect in cognitive and/or sexual decline during ageing of rats [37], so selegiline can be considered a senolytic drug.

Only a few reports have been dealing with the MAO activity in the rabbit eye [38]. Ocular hypotensive effect [39] was found in rabbits following topical administration of clorgyline, the selective and irreversible MAO-A inhibitor. Single administration of clorgyline caused a clinically sig- nificant decrease in the intraocular pressure, however, treatment with selegiline was practically ineffective in patients with glaucoma. Mallampali et al. [40] found nonreactive pupils as a consequence of overdose of MAO inhibitors. Bausher [41] reported detection and identification of both MAO-A and MAO-B in iris-ciliary body of albino rabbits. Zeller et al. [42] differentiated the effect of topical use of inhibitors of MAO-A and MAO-B on the rabbit iris. When a monoamine-releasing compound (Ro-1284) was given to the majority of its effects was prevented by selegiline [42].

Selegiline definitively protected the retina from the damage caused by the intravitreal injection of NMDA [43]. Selegiline protection meant that neither a decrease in the density of the ganglion cells nor in the thickness of the inner plexiform layer could be observed. Ragaiey et al. [32] reported that selegiline $(0.01$ through $100 \mu \mathrm{M})$ dosedependently increased the survival rate of immortalized rat retinal precursor cells and prevented injured retinal precursor cells from apoptosis. At the same time, selegiline failed to promote significant axonal regeneration of rat ganglion cells of the retina [44].

Buys et al. [45] concluded that after an experimental crash of optic nerve, selegiline could significantly facilitate the survival of ganglion cells of the rat retina.

We have also demonstrated very high selegiline levels in the testes during the whole experimental period. The same phenomenon was found in rats [30]. The peak concentrations of selegiline in the testes are comparable to those measured in the serum, but the selegiline concentrations in the testes show slower decline than in the serum. The distribution of selegiline in the testes and possibly in the seminal plasma and an increased copulation ability of rats, and also that of humans may be coincidental. The elevated concentration of monoamine oxidase in human seminal plasma was found to be a parallel phenomenon with infertility [46]. Mihalik et al. [47] recently published experimental proofs that deprenyl highly improves reproductive capacity of male rats.

Based on reports on the MAO inhibitor pargyline and clorgyline - their inhibitory effect on testicular MAO activity - it is strongly suggested that selegiline has also the ability to inhibit MAO in the testes and in the seminal plasma.

\section{CONCLUSION}

Fine and precise dissection of eye compartments was made possible when rabbits were used as model subjects of our experiments. Differentiation by the dissection of various eye compartments (such as the retina, cornea, iris, lacrimal gland and intraocular lens) is of basic importance, as the retina belongs to the central nervous system. This fact is also mirrored by pharmacokinetic data as a delayed maximum level in the retina compared to cornea and iris. The extremely high selegiline level in the lacrimal gland and its definitely late tissue level maximum require further physiological and pharmacological investigations.

Selegiline is distributed in all body compartments that contain monoamine oxidase B enzyme. Our new experimental findings on high selegiline tissue levels in the testis, lacrimal gland and other eye segments open the question, how 
physiological functioning of these organs are influenced by therapeutic administration of selegiline.

\section{CONFLICT OF INTEREST}

The authors confirm that this article content has no conflict of interest.

\section{ACKNOWLEDGEMENTS}

This work was financially sponsored by the Hungarian National Granting Agency, OTKA 100155. Cooperation and advice of Dr. Tálosi, L.; Mrs. Guth, Györgyike; Ms Proszenikov, Anita; Mr. Horváth, János are appreciated.

\section{REFERENCES}

[1] Standaert, D.G.; Young, A.B. In: Goodman\&Gilman's The Pharmacological Basis of Therapeutics, 11/E; Brunton, L.L.; Lazo, J.S.; Parker, K.L. Eds. McGraw-Hill Medical Publishing Division: New York,2006, pp. 529-538.

[2] Magyar, K.; Pálfi, M.; Tábi, T.; Kalász, H.; Szende, B.; Szökő, É. Pharmacological aspects of (-)-deprenyl. Curr. Med. Chem., 2004, 11,2017-2031.

[3] Marutle, A.; Gillberg, P.G.; Bergfors, A.; Yu, W. Ni, R.; Nennesmo, I.; Voytenko, L.; Nordberg, A. ${ }^{3} \mathrm{H}$-deprenyl and ${ }^{3} \mathrm{H}-\mathrm{PIB}$ autoradiography show different laminar distributions of astroglia and fibrillar $\beta$-amyloid in Alzheimer brain. J. Neuroinflammation., 2013, 10, 90 .

[4] Knoll, J.; Magyar, K. Some puzzling pharmacological effects of monoamine oxidase inhibitors. Adv. Biochem. Psychopharmacol., 1972, 5, 393-408.

[5] Tekes, K. In: Monoamine oxidase inhibitors and their role in neurotransmission (drug development); Török, T.; Klebovich I., Eds.; Medicina Publishing House, Budapest, 2004, pp. 377-387.

[6] Tekes, K.; Magyar, K. Effect of MAO inhibitors on the highaffinity reuptake of biogenic amines in rat subcortical regions. Neurobiology (Budapest), 2000, 8(3-4), 257-264.

[7] Tekes, K.; Tóthfalusi, L.; Gaál, J.; Magyar, K. Effect of MAO inhibitors on the uptake and metabolism of dopamine in rat and human brain. Pol. J. Pharmacol. Pharm., 1988, 40(6), 653-658.

[8] Magyar, K.; Knoll, J. Selective inhibition of the "B form" of monoamine oxidase. Pol. J. Pharmacol. Pharm., 1977, 29(3), 233-246.

[9] Kitani, K.; Minami, C.; Isobe, K.; Maehara, K.; Kanai, S.; Ivy, G.O.; Carrillo, M.C. Why (-)deprenyl prolongs survivals of experimental animals: increase of anti-oxidant enzymes in brain and other body tissues as well as mobilization of various humoral factors may lead to systemic anti-aging effects. Mech. Ageing Dev., 2002, 123(8),1087-1100.

[10] Kitani, K.; Minami, C.; Isobe, K.; Maehara, K.; Kanai, S.; Ivy, G.O.; Carrillo, M.C. Why (-)deprenyl prolongs survivals of experimental animals: increase of anti-oxidant enzymes in brain and other body tissues as well as mobilization of various humoral factors may lead to systemic anti-aging effects. Mech. Ageing Dev., 2002, 123(8), 1087-1100.

[11] Bickford, P.C.; Adams, C.E.; Boyson, S.J.; Curella, P.; Gerhardt, G.A.; Heron, C.; Ivy, G.O.; Lin, A.M.; Murphy, M.P.; Poth, K.; Wallace, D.R.; Young, D.A.; Zahniser, N.R.; Rose, G.M. Longterm treatment of male F344 rats with deprenyl: assessment of effects on longevity, behavior, and brain function. Neurobiol. Aging, 1997, 18(3), 309-318.

[12] Tatton, W.G.; Chalmers-Redman, R.M.; Ju, W.J.; Mammen, M.; Carlile, G.W.; Pong, A.W.; Tatton, N.A. Propargylamines induce antiapoptotic new protein synthesis in serum- and nerve growth factor (NGF)-withdrawn, NGF-differentiated PC-12 cells. J. Pharmacol. Exp. Ther., 2002, 301(2), 753-764.

[13] Brandeis, R.; Sapir, M.; Kapon, Y.; Borelli, G.; Cadel, S.; Valsecchi, B. Improvement of cognitive function by MAO-B inhibitor Ldeprenyl in aged rats. Pharmacol. Biochem. Behav., 1991, 39(2), 297-304.
[14] Yen, T.T.; Knoll, J. The aphrodisiac effect of low doses of (-) deprenyl in male rats. Pol. J. Pharmacol. Pharm., 1982, 34(5-6), 303308.

[15] Dalló, J.; Lekka, N.; Knoll, J. The ejaculatory behavior of sexually sluggish male rats treated with (-)deprenyl, apomorphine, bromocriptine and amphetamine. Pol. J. Pharmacol. Pharm., 1986, 38(3), 251-255.

[16] Knoll, J.; Dalló, J.; Yen, T.T. Striatal dopamine, sexual activity and lifespan. Longevity of rats treated with (-)deprenyl. Life Sci., 1989, 45(6), 525-531.

[17] Sharpe,M.A.; Han, J.; Baskin,A.M; Baskin,S. D. Design and Synthesis of a MAO-B-Selectively Activated Prodrug Based on MPTP: A Mitochondria-Targeting Chemotherapeutic Agent for Treatment of Human Malignant Gliomas. ChemMedChem. 2015,10(4), 621628.

[18] Laine, K.; Anttila, M.; Helminen, A.; Karnani, H.; Huupponen, R. Dose linearity study of selegiline pharmacokinetics after oral administration: Evidence for strong drug interaction with female sex steroids. British J. Clin. Pharmacol., 1999, 47(3), 249-254.

[19] Wang, H.; Tompkins, L.M. CYP2B6: new insights into a historically overlooked cytochrome P450 isozyme. Curr. Drug Metab., 2008, 9(7), 598-610.

[20] Kalász, H.; Benkő, B.; Gulyás, Zs.;Tekes, K. Lipophilicity determination using both TLC and calcultions, J. Liquid Chromatogr. \& Rel. Techn. 2009, 32, 1-17.

[21] Szatmári, I. In: Milestones in monoamine oxidase research: discovery of (-)-deprenyl; Magyar, K. and Vizi, E.S. Eds.; Medicina Publishing House, Budapest, 2000, pp. 61-80.

[22] Benetton, S.A.; Fang, C.; Yang, Y.O.; Alok, R.; Year, M.; Lin, C.C.; Yeh, L.T. P450 phenotyping of the metabolism of selegiline to desmethylselegiline and methamphetamine. Drug Metab. Pharmacokinet., 2007, 22(2), 78-87.

[23] Dragoni, S.; Bellik, L.; Frosini, M.; Sgaragli, G.; Marini, S.; Gervasi, P.G.; Valoti, M. 1-Deprenyl metabolism by the cytochrome P450 system in monkey (Cercopithecus aethiops) liver microsomes. Xenobiotica, 2003, 33(2), 181-195.

[24] Kamada, T.; Chow, T.; Hiroi, T.; Imaoka, S.; Morimoto, K.; Ohde, H.; Funae, Y. Metabolism of selegiline hydrochloride, a selective monoamine b-type inhibitor, in human liver microsomes. Drug Metab. Pharmacokinet., 2002, 17(3), 199-206.

[25] Benetton, S.A.; Fang, C.; Yang, Y.O.; Alok, R.; Year, M.; Lin, C.C.; Yeh, LT. P450 phenotyping of the metabolism of selegiline to desmethylselegiline and methamphetamine. Drug Metab. Pharmacokinet., 2007, 22(2), 78-87.

[26] Tóth-Molnár, E.; Hollósi, I.; Soós, E.; Lengyel, J.; Furst, Z.; Kalász, H. In Monoamine oxidase inhibitors and their role in neurotransmission (drug development), Török, T.; Klebovioch I., Eds.; Medicina Publishing House, Budapest, 2004, pp. 351-362.

[27] Al-Dhubiab, B.E.; Nair, A.B.; Kumria, R.; Attimarad, M.; Harsha, S. Development and evaluation of buccal films impregnated with selegiline-loaded nanospheres. Drug Deliv. 2014, Sep 3, 1-9. [Epub ahead of print]

[28] Tábi, T.; Szökő, É.; Vécsei, L.; Magyar, K. The pharmacokinetic evaluation of selegiline ODT for the treatment of Parkinson's disease. Expert Opin. Drug Metab. Toxicol., 2013, 9(5), 629-636.

[29] Bitsios, P.; Langley, R.W.; Tavernor, S.; Pyykkö, K.; Scheinin, M.; Szabadi, E.; Bradshaw, C.M. Comparison of the effects of moclobemide and selegiline on tyramine-evoked mydriasis in man. $\mathrm{Br}$. J. Clin. Pharmacol., 1998, 45(6), 551-558.

[30] Tekes, K.; Pöstényi, Z.; Faigl, E.B.; Magyar, K.; Polyák, A.; Trencsényi, Gy.; Balogh, L.; Kalász, H. Distribution of N-methyl${ }^{14} \mathrm{C}$-labeled selegiline in the rat. J. Pharm. Biomed. Anal., 2015, $111,147-152$.

[31] Fernandez de Arriba, A.; Balsa, D.; Tipton, K.F.; Unzeta, M. Monoamine oxidase and semicarbazide-sensitive amine oxidase activities in bovine eye. J. Neural. Transm. Suppl., 1990, 32, 327330.

[32] Ragaiey, T.; Ma, J.X.; Jiang, W,J.; Greene, W.; Seigel, G.M., Stewart, W.C. L-deprenyl protects injured retinal precursor cells in vitro. J. Ocul. Pharmacol. Ther., 1997, 13(5):479-488.

[33] Xu, L.; Ma, J.; Seigel, G.M.; Ma, J.X. 1-Deprenyl, blocking apoptosis and regulating gene expression in cultured retinal neurons. Biochem. Pharmacol., 1999, 58(7), 1183-1190.

[34] Pöstényi, Z.; Tekes, K.; Tóth-Molnár, E.; Kalász, H.: HPLC analysis of blood-brain penetration of 4-fluorodeprenyl. $J$. Pharm. Biomed. Anal., 2015, 102, 529-534. 
[35] Kalász, H.; Kerecsen, L.; Knoll, J.; Pucsok, J. Chromatographic studies on the binding, action and metabolism of (-)-deprenyl. $J$. Chromatogr., 1990, 499, 589-599.

[36] Martin, X.D.; Brennan, M.C. Dopamine and its metabolites in human tears. Eur. J. Ophthalmol. 1993,3(2):83-88.

[37] Kumar, P. S. M.; Sheba,M.J.; Kumar, M.; Quadri S.K. Deprenyl stimulates the release of luteinizing hormone from the pituitary in vitro. Life Sciences, 1997, 61(18), 1783-1788.

[38] Lindvall, M.; Owman, C. Evidence for the presence of two types of monoamine oxidase in rabbit choroid plexus and their role in breakdown of amines influencing cerebrospinal fluid formation. $J$. Neurochem., 1980, 34(3), 518-522.

[39] Maeda, I.; Ueda, T.; Koide, R.; Inatomi, M.; Fukado, Y.; Uchida, E.; Oguchi, K.; Yasuhara, H. Ocular hypotensive effects of monoamine oxidase-A inhibitors in rabbit. Japan J. Ophthalmol., 1988, 32(2), 211-218.

[40] Mallampalli, R.; Pentel, P.R.; Anderson, D.C. Nonreactive pupils due to monoamine oxidase inhibitor overdose. Crit. Care Med., 1987, 15(5), 536-537.

[41] Bausher, L.P. Identification of A and B forms of monoamine oxidase in the iris-ciliary body, superior cervical ganglion, and pineal gland of albino rabbits. Invest. Ophthalmol., 1976, 15(7), 529-537
[42] Zeller, E.A.; Knepper, P.A.; Shoch, D. Differential effects of inhibitors of monoamine oxidase types $\mathrm{A}$ and $\mathrm{B}$ on the adrenergic system of the rabbit iris. Invest. Ophthalmol., 1975, 14(2), 155-159.

[43] Takahata, K.; Katsuki, H.; Kobayashi, Y.; Muraoka, S.; Yoneda, F.; Kume, T.; Kashii, S.; Honda, Y.; Akaike, A. Protective effects of selegiline and desmethylselegiline against N-methyl-Daspartate-induced rat retinal damage. Eur. J. Pharmacol., 2003, 458(1-2), 81-89.

[44] Rosenstiel, P.; Sievers, J.; Lucius, R. (-)-Deprenyl fails to promote axonal regeneration of retinal ganglion cells in vitro and in vivo. Cell Tissue Res. 2002, 308(2), 167-175.

[45] Buys, Y.M.; Trope, G.E.; Tatton, W.G. (-)-Deprenyl increases the survival of rat retinal ganglion cells after optic nerve crush. Curr. Eye Res., 1995, 14(2), 119-126.

[46] Roberge, A.G.; Moufarege, A.; Lavoie, J.; Roberge, C.; Tremblay, R.R. Biochemical properties and kinetic parameters of monoamine oxydase in human seminal plasma. Int. J. Fertil., 1984, 29(3), 180185.

[47] Mihalik, J.; Mašlanková, J.; Solár, P.; Horváthová, F.; Hubková, B.; Almášiová, V.; Šoltés,J.; Švaňa, M.; Rybárová, S.; Hodorová, I. The effect of R-(-)-deprenyl administration on reproductive parameters of rat males. Eur. J. Pharmacol., 2015, 754, 148-152. 